Click www.researchjournal.co.in/online/subdetail.html to purchase.

\title{
Performance evaluation of different weeders in cotton
}

\author{
Aman Mor, N.K. Bansal, Parveen, Nitin Karwasra and Sushil Kumar
}

Received : 18.07.2020; Revised : 20.08.2020; Accepted : 21.09.2020

See end of the Paper for authors' affiliation

Correspondence to :

\section{Parveen}

Department of Farm Machinery and Power

Engineering, Punjab Agricultural University, Ludhiana (Punjab) India Email: parveenfmpe@ gmail.com
- ABSTRACT : The present study was carried out to predict the performance different type's weeder in cotton crop so that efficient machine can be selected by farmer. The crop and machine performance parameter were recorded at three stages of cotton crop i.e. pre-square, square and flowering. The soil resistance was recorded before, just after weeding ( $3^{\text {rd }}$ stage) and at the time of harvest. Yield data (g/plant) was recorded under all the treatments taken in both varieties. The weeding efficiency of different weeder was found between 74 to 89 per cent. The field capacity of tractor operated inter row rotary weeder was in the range of 0.54 to $0.59 \mathrm{ha} / \mathrm{h}$ whereas it was $0.8 \mathrm{ha} /$ $\mathrm{h}$ in tractor operated high clearance cultivator, $0.16 \mathrm{ha} / \mathrm{h}$ with engine operated power weeder and $0.05 \mathrm{ha} / \mathrm{h}$ with manual hand hoe. The per cent saving in cost of operation with mechanical weeder over manual hand hoe was in the range of 80 to 93 . The B:C ratio of mechanical weeder selected for study was in the range of 1.57 to 4.4 and payback period was in the range of 0.44 to 1.7 years. Time saving over manual hand hoe in weeding operation with the use of tractor operated weeder was 90 to 93 per cent whereas in engine operated weeder it was 68.7 per cent over manual hand hoe. The per cent saving in labour requirement with the use of mechanical weeder was in the range of 96 to 99 per cent over manual hand hoe. From result obtained from the study tractor operated weeder (operating width $=1500 \mathrm{~mm}$ ) was found suitable for cotton crop.

- KEY WORDS : Cotton, Weeder, Hand hoe, Cultivator, Field capacity

- HOW TO CITE THIS PAPER : Mor, Aman, Bansal, N.K., Parveen, Karwasra, Nitin and Kumar, Sushil (2020). Performance evaluation of different weeders in cotton. Internat. J. Agric. Engg., 13(2) : 227-236, DOI: 10.15740/HAS/IJAE/13.2/227-236. Copyright@2020: Hind Agri-Horticultural Society. 